\title{
Andragogic strategies for English language oral communication improvement
}

\section{Estrategias andragógicas para el mejoramiento de la comunicación oral}

\section{en el idioma inglés}

1 Noemi Mercedes Remache Carrillo

(iD) https://orcid.org/0000-0002-0205-0410 Unidad Educativa Riobamba, Riobamba, Chimborazo, Ecuador noemi.remache@educación.gob.ec

2 Sandra Paulina Porras Pumalema Escuela Superior Politécnica de Chimborazo, Carrera de Mantenimiento Industrial, Riobamba, Chimborazo, Ecuador sandra.porras@espoch.edu.ec

3 María Eugenia Rodríguez Durán Escuela Superior Politécnica de Chimborazo, Carrera de Gestión de Transporte, Riobamba, Chimborazo, Ecuador mariae.rodriguez@espoch.edu.ec

4 Patricia Pilar Moyota Amaguaya Escuela Superior Politécnica de Chimborazo, Carrera de Ingeniería Automotriz, Riobamba, Chimborazo, Ecuador patricia.moyota@espoch.edu.ec

Artículo de Investigación Científica y Tecnológica Enviado: $10 / 11 / 2021$

Revisado: $25 / 11 / 2021$

Aceptado: $21 / 12 / 2021$

Publicado:05/01/2022

DOI: https://doi.org/10.33262/ap.v4i1.131

Cítese: improvement. AlfaPublicaciones, 4(1), 62-76. https://doi.org/10.33262/ap.v4i1.131

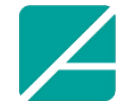

Ciencia Digital

ALFA PUBLICACIONES, es una Revista Multidisciplinar, Trimestral, que se publicará en soporte electrónico tiene como misión contribuir a la formación de profesionales competentes con visión humanística y crítica que sean capaces de exponer sus resultados investigativos y científicos en la misma medida que se promueva mediante su intervención cambios positivos en la sociedad. https://alfapublicaciones.com

La revista es editada por la Editorial Ciencia Digital (Editorial de prestigio registrada en la Cámara Ecuatoriana de Libro con No de Afiliación 663) www.celibro.org.ec 


\section{Palabras claves:} comunicación oral, estrategias andragógicas, educación superior, fluidez, pronunciación, gramática, vocabulario.

\section{Resumen}

Introducción: teniendo en cuenta que los estudiantes universitarios son adultos jóvenes, se necesita otra forma de enseñar. En este contexto, se deben aplicar estrategias andragógicas para potenciar su proceso de aprendizaje del idioma inglés. Objetivo: esta investigación tiene como objetivo aplicar estrategias andragógicas en el contexto del teletrabajo para el mejoramiento de la comunicación oral en inglés de los estudiantes de primer semestre de la carrera de mantenimiento industrial de la Escuela Superior Politécnica de Chimborazo durante el periodo académico octubre 2020 - marzo 2021. Metodología: Este estudio implementó una investigación cuasi - experimental, descriptiva y mixta. Para lograr el propósito de esta investigación, participaron dos grupos focales. Participaron 80 alumnos del primer semestre de la carrera de Mantenimiento Industrial. Los estudiantes pertenecientes al paralelo A formaron el grupo de control y los alumnos que estaban matriculados en el paralelo B formaron el grupo experimental con un mismo número de estudiantes. $\mathrm{Al}$ inicio del semestre, los estudiantes realizaron un pre-test; después de eso, los resultados fueron condensados y analizados. Debido a los bajos puntajes, las investigadoras planificaron una intervención en el aula que se centró en el uso de estrategias andragógicas, a saber, discusiones, resolución de problemas, simulaciones, proyectos y análisis, para mejorar las habilidades de comunicación oral de los estudiantes. Tras finalizar la intervención, los alumnos realizaron el post-test con las mismas características. El pre-test y el post-test contenían las preguntas de la parte oral del PET (Preliminary English Exam). Resultados: Luego de recolectar los datos, estos fueron analizados a través de un software estadístico. Se compararon las medias de cada grupo tanto para el pretest como para el post-test. En el pre-test se evidenció un nivel igual de desempeño oral en inglés; sin embargo, en el post test existió una diferencia significativa. Los estudiantes pertenecientes al grupo experimental obtuvieron una media de 5,48 para el pretest; y en el post-test obtuvieron 11,40. Por otro lado, los estudiantes que pertenecieron al grupo de control mantuvieron el mismo nivel de desempeño en inglés. Conclusión: Las estrategias andragógicas son adecuadas y útiles para ser utilizadas en la educación superior para mejorar las habilidades de comunicación oral de los 
Keywords: oral communication, andragogic strategies, higher education, fluency, pronunciation, grammar, vocabulary factors. estudiantes; por lo tanto, los docentes deben utilizarlos para contribuir con su mejora.

\section{Abstract}

Introduction: taking into consideration that university students are young adults, another way of teaching is needed. In this context, andragogic strategies must be applied to enhance their English language learning process. Objective: this research aims to apply andragogic strategies in the context of telework for the improvement of English oral communication of first-semester students of the industrial maintenance career of the Higher Polytechnic School of Chimborazo during the academic period October 2020 - March 2021. Methodology: This study implemented a quasi-experimental, descriptive, and mixed research. To achieve the purpose of this research, two focal groups took part. 80 students from the first semester of the Industrial Maintenance participated. The students belonging the parallel A formed the control group and the students who were registered in the parallel B formed the experimental group. The groups had the same number of students. At the beginning of the semester, the students took a pre-test; after that, the results were condensed and analyzed. Due to the low scores, the researchers planned a classroom intervention that focused the use of andragogic strategies namely discussions, problem solving, simulations, projects and analysis, to improve the students' oral communication skills. After finishing the intervention, the students took the posttest with the same characteristics. The pre-test and the post-test had the speaking part of the PET (Preliminary English Exam). Results: After gathering data, they were analyzed through a statistical software. The means of each group were compared for the pre-test and the post-test as well. In the pre-test an equal level of English oral performance was evidenced; however, in the post test, a significant difference existed. The students belonging the experimental group obtained a mean of 5.48 for the pre-test; on the contrary, they obtained 11.40 in the post-test. On the other hand, the students who belonged the control group, kept the same level of English performance. Conclusion: Andragogic strategies are suitable and helpful to be used in the higher education to improve the students' oral communication skills; therefore, teachers must use them to contribute with their improvement. 


\section{Introduction}

Man is a natural, active, conscious being, who is in constant relationship with the sociocultural environment with a fervent desire to learn every day. Faced with this reality, education appears to promote his or her integral development and motivate him or her to learn to apprehend, to do, to be, and to develop critical and reflective thinking that encourages the personal improvement in the environment where he or she operates.

Globalization asks for constant changes, where knowing a universal language like English allows crossing borders and helps to be more competitive. In this way, all life experiences related to the English language make sense when it is possible to combine them with the new knowledge acquired in the classroom in search of useful and practical information that can be used in solving problems.

The adult is an individual, unique and diverse person, therefore, different, special and unrepeatable; he is the bearer of a personal life story and an ideal of his own that gives meaning to his existence. Adult learning consists of processing varied information, for this, organize, classify and generalize it effectively, that is, learn by understanding, first understand and then memorize. The teacher is the guide that helps participants to internalize the knowledge of the English Language responsibly.

The adult learning methodology focuses on how to plan, manage and direct educational praxis, enriching the general knowledge that the student has and complementing it with new knowledge.

On the other hand, today, communication is vital in the development of human beings everywhere. For this reason, communicational forms have been evolving in a dizzying way, mainly due to the incorporation of technology as a tool that facilitates this purpose, such as social networks, email, videoconferences, among other applications, which people use more and more.

Despite all this innovation achieved in the field of communication through the digital world, oral language continues to be the main form of communication between people around the world. The existence of a variety of languages in universal society constitutes a limitation to achieve effective communication between peoples. To overcome this limitation already mentioned, a common language has been established to facilitate communication on a planetary scale, this is the English language (Cristal, 2003).

In the academic and scientific fields, the English language has established itself on a global scale (Council of Europe, 2001). The greatest amount of information, advances and discoveries are communicated through this language, in these conditions the knowledge of the English language becomes more and more necessary. 
In the Ecuadorian educational system, the learning of English is contemplated from the basic education levels (Ministerio de Educación del Ecuador, 2016). However, the results after completing basic education, high school and even higher education, professionals for the most part fail to acquire a proficiency in communication in this language (Peña, 2019). The reasons are: first, the socio-educational context of Ecuador which does not allow frequent use of English. In these conditions, the students face demotivation for learning this language (Ortega \& Fernández, 2017). The lack of training and updating of English teachers in the use and management of teaching methodologies and techniques, to stimulate learning in this subject to produce significant learning of the English language (Machado, 2019). Finally, the limited infrastructure available to educational institutions does not contribute to the effective learning of this language (Peña, 2019).

Furthermore, due to the COVID-2019 pandemic, higher education students have been experienced an adverse reality in learning English. All these circumstances have led to several problems that are detrimental to their English improvement. For this reason, it is necessary to use andragogic strategies that stimulate the student to be involved in the educational process with flexibility.

Consequently, this research aims to apply andragogic strategies in the context of telework for the improvement of English oral communication of first-semester students of the industrial maintenance career of the e Higher Polytechnic School of Chimborazo during the academic period October 2020 - March 2021.

\section{Andragogy}

The Society of the XXI Century is characterized by processes of change and transformation, where it is important that the human being learns throughout life, in this sense, it is currently the andragogic processes of teaching-learning, that is, the adult education.

According to UNESCO (2010), adult learning and education are at the center of a necessary paradigm shift towards lifelong learning, for all as a coherent and meaningful framework for the provision and practice of education and training. That is the reason why it is necessary to move from processes of teaching to processes aimed at learning, where adults' prior knowledge and experiences could be considered to generate meaningful learning.

Andragogy, according to Knowles (1976), allows to know the most pertinent educational principles and processes based on the characteristics, needs, experiences and interests of adults. In this sense, it is necessary to adapt the educational models that 
are used in different educational systems and modalities according to andragogic principles.

Knowles et al. (2001) stated the following premises in the design and development of activities to classes with the andragogic approach:

1. The need to know: For adults it is very important to know the reason for learning.

2. The self-concept of the students: It is very important to take into consideration the students' prior knowledge because they have already a lot of experience.

3. The role of students' experiences: throughout their lifetime, adults have enriching experiences that should be considered when generating the educational process with them in such a way that they work in a meaningful way, articulating the new knowledge with the previous knowledge. It also represents a challenge, since there is greater heterogeneity in terms of their interests, profiles, expectations, in addition to the fact that sometimes teachers who work with adults also face the blocks that adults must acquire new knowledge.

4. Willingness to learn: this characteristic is related to the usefulness they find in learning, the greater the utility identified, the greater the disposition they present to learn.

5. Orientation towards learning: orientation is focused on the life of the adult; therefore, it is advisable to start from their context, needs, and interests.

6. Motivation: it is a key factor for the success of adult learning. Examples of external motivation are a better job or increase the salary, while internal ones are increasing job satisfaction, self-esteem, and quality of life.

Considering these premises at the time of designing and developing adult-oriented learning activities will allow working from an approach centered on the andragogic model and generating a meaningful educational process that allows the expected learning results to be achieved.

After reflecting on andragogy from different theoretical positions, it is clearly observed that this science is conceived from an integral perspective, which is oriented to the growth of the person in all its areas as well as in the awareness and transformation of their context (Castillo, 2014).

\section{English Oral communication}

One of the productive skills of the language is oral expression (speaking) as remarked by Harmer (2007b); which is a gradual process aimed at students to practice the language in real settings through dialogues, debates and other strategies that lead to the 
development of oral expression of English (Richards \& Rodgers, 1987). Oral expression is perhaps the most important skill from the communicative approach since through it allows to establish the level of communication in this foreign language that the student has achieved (Arifin, 2020).

Given that adult learning focuses on problems rather than content and that it focuses on life and the challenges or problems that arise every day (Clardy, 2005); it is necessary for the adult to learn by doing, by application and experience, or by trial and error. Adults do not simply receive knowledge created by others but examine it considering their own reality and make their own analysis. Practice is the main characteristic of adult learning to transform their reality. Adult learning is an ongoing process of inquiry and exploration combined with reflective action on this action, leading to further investigation (Knowles et al., 2001).

According to Harmer (2007a), there are some oral subskills that students must enhance on namely pronunciation, fluency, vocabulary, and grammar. Pronunciation refers to the ability to use the correct stress, rhythm and intonation in a spoken language (Barberán, 2007). Fluency is the ability to produce the language naturally and capable of producing a message that is understandable (Dewi et al., 2017). Furthermore, using appropriate vocabulary is essential to comprehension and communication (Ahmed, 1989). On the other hand, grammar deals with the management of rules that make speakers accurate (Arifin, 2020).

Based on those concepts, some Andragogic strategies such as discussion, analysis, simulation, projects, demonstrations and problem solving to improve students' oral communication in the English language were addressed under the communicative approach.

\section{Methodology}

The methodology for this study was centered in the use of andragogic strategies for the improvement of English language oral communication namely pronunciation, fluency, vocabulary, and grammar. In doing this, the application of andragogic strategies in the improvement of students' oral skills was done through quasi-experimental research with mixed approach and descriptive scope. The target population for this study was divided into two groups which come from the lists that the academic system provides. It was distributed as is detailed in the table 1: 


\section{Table 1}

Population. - Escuela Superior Polytechnical De Chimborazo, students from the industrial maintenance career

\begin{tabular}{cccccc}
\hline SEMESTER & CLASS & MALE & FEMALE & TOTAL & GROUPS \\
\hline 1 & $\mathrm{~A}$ & 32 & 8 & 40 & ExperimentalGroup \\
1 & $\mathrm{~B}$ & 30 & 10 & 40 & Control group \\
\hline \hline TOTAL & & 62 & 18 & 80 & \\
\hline
\end{tabular}

Created by: Remache (2022)

During the starting week of the October 2020- March 2021 academic period, the students took a diagnostic test based on the speaking part of PET (Preliminary English Test) which is available in the Cambridge Assessment web page. The exam was graded by using a rubric to obtain data. Furthermore, the gathered data was taken into consideration to implement an academic intervention to enhance the students' oral skills. At the end of the academic period, the same test was taken by the students as the post-test to compare results. Besides, the statistical analysis was performed through SPSS software.

Since there were two groups of study, both took English classes with topics in accordance with the planned syllabus. However, the intervention for the experimental group was based on the use of the andragogic strategies while the students from the control group worked with their regular classes.

\section{Results}

As it was mentioned before, the total population took a survey to convey their own perceptions in their level of English. This survey was designed using a questionnaire in Moodle. After data collection, a database was devised for further analysis as shown in the table 2 .

Table 2

Pre-test and post-test. Control group

\begin{tabular}{ccccc}
\hline Criteria & Pre - test & Percent & Post - test & Percent \\
\hline Pronunciation & 1.18 & $5.9 \%$ & 1.55 & $7.8 \%$ \\
\hline Fluency & 1.30 & $6.5 \%$ & 1.53 & $7.7 \%$ \\
\hline Vocabulary & 1.28 & $6.4 \%$ & 1.50 & $7.5 \%$ \\
\hline Grammar & 1.28 & $6.4 \%$ & 1.55 & $7.8 \%$ \\
\hline Expected Score & 5.04 & $25.2 \%$ & 6.13 & $30.7 \%$ \\
\hline
\end{tabular}

Created by: Remache (2022) 
Regarding to the results in the control group, in the pretest, the average is 5.04 out of 20 which is the expected score. On the other hand, the results from the post-test are slightly different. The mean for the whole group is 6.13 out of 20 which represents $30.7 \%$ of the expected score.

These data clearly show that students from the control group keep the same low level of oral communication. Therefore, an intervention could be also suitable for them, as detailed in the table 3 .

Table 3

Experimental group - Pre-test and post-test

\begin{tabular}{ccccc}
\hline Criteria & Pre - test & Percent & Post - test & Percent \\
\hline Pronunciation & 1.38 & $6.9 \%$ & 2.79 & $14.0 \%$ \\
\hline Fluency & 1.32 & $6.6 \%$ & 2.82 & $14.1 \%$ \\
\hline Vocabulary & 1.42 & $7.1 \%$ & 2.87 & $14.4 \%$ \\
\hline Grammar & 1.35 & $6.8 \%$ & 2.95 & $14.8 \%$ \\
\hline & 5.47 & $27.4 \%$ & 11.43 & $57.2 \%$ \\
\hline Expected score & 20.00 & $100 \%$ & 20.00 & $100 \%$
\end{tabular}

Created by: Remache (2022)

In the pre-test, the experimental group obtained 5.47 which represents $27.4 \%$. This information implies that students have a low level in oral communication skills because it does not even achieve half of the expected score. After the intervention phase, the students in this group achieved a mean of 11.43 which represents $57.2 \%$ of the expected score. It means that the intervention focused on the use of andragogic strategies has good results.

After this process, the means were compared in a T-test through SPSS statistical software as itemized in the table 4 .

Table 4

Means comparison. Pre-test. - Group Statistics

\begin{tabular}{llrrrr}
\hline & Group & N & Mean & Std. Deviation & Std. Error Mean \\
\hline Pre-test & Control group & 40 & 5.04 & 1.860 & .294 \\
& Experimental group & 40 & 5.47 & 2.100 & .332
\end{tabular}

Created by: Remache (2022)

In this case, the table above shows that the control group has a mean of 5.03; similarly, the experimental group has 5.48. This signifies that both the control group and the experimental group have the same level of oral communication. It must be remarked that 
both are in a low level of performance according to the rubric. The results are displayed below in the table 5 .

\section{Table 5}

T-test: Pre-test. - Independent Samples Test

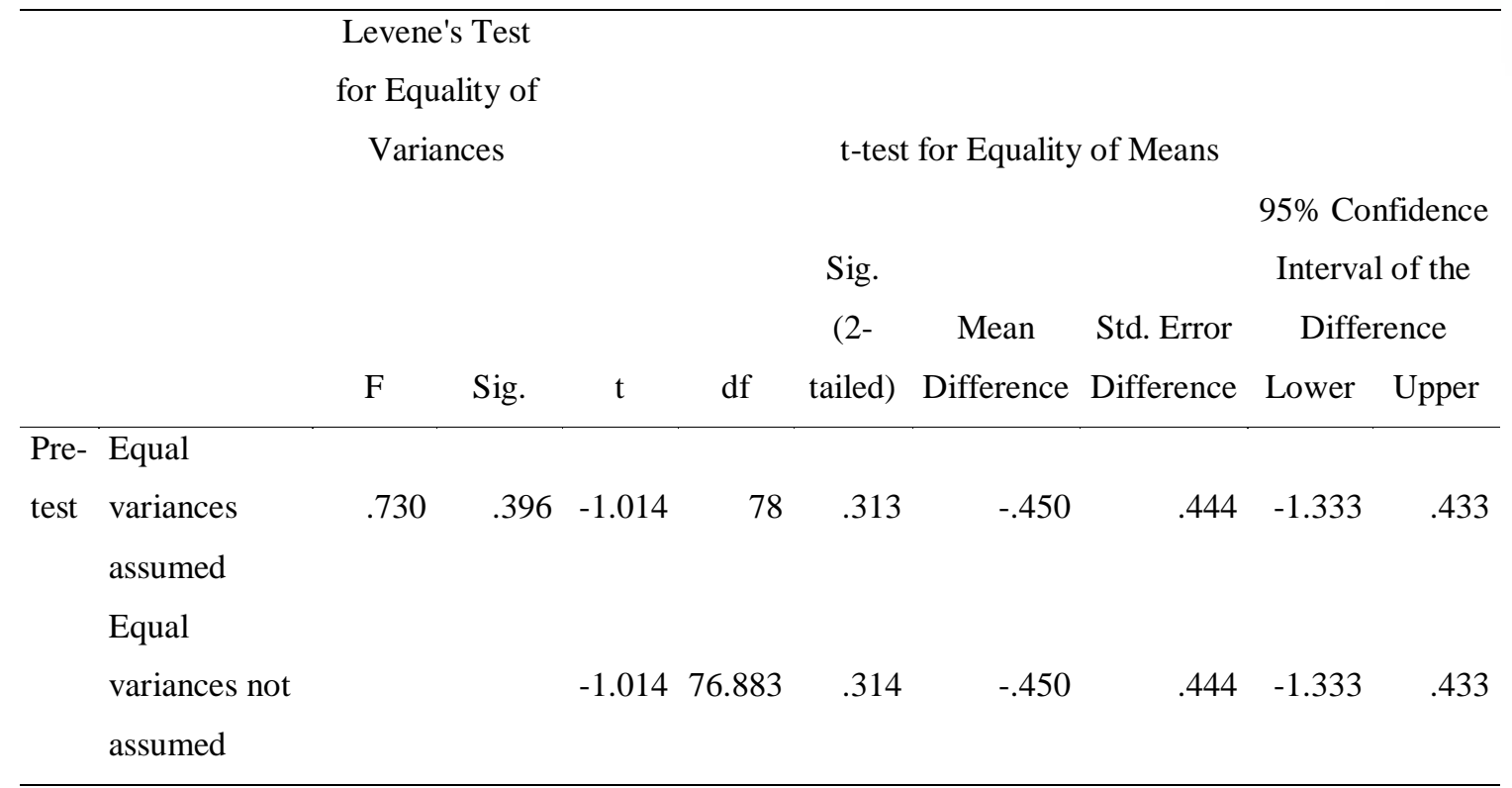

Created by: Remache (2022)

With confidence interval of difference of $95 \%$, it is proved that in the Levene's test there are equal variances assumed with a p. significance of .396 which is $>$ than .005 . Besides, the 2 -tailed significance is .313 which is $>.005$. This shows that both the control and the experimental groups are in the same level of oral communication in the English language.

On the other hand, the comparison of means for the post-test are shown in the table 6.

\section{Table 6}

T-test: Post-test

\begin{tabular}{|c|c|c|c|c|c|}
\hline \multicolumn{6}{|c|}{ Group Statistics } \\
\hline & Group & $\mathrm{N}$ & Mean & Std. Deviation & Std. Error Mean \\
\hline \multirow[t]{2}{*}{ Post-test } & Control group & 40 & 6.13 & 3.073 & .486 \\
\hline & $\begin{array}{l}\text { Experimental } \\
\text { group }\end{array}$ & 40 & 11.40 & 2.416 & .382 \\
\hline
\end{tabular}




\section{Table 6}

T-test: Post-test (continuación)

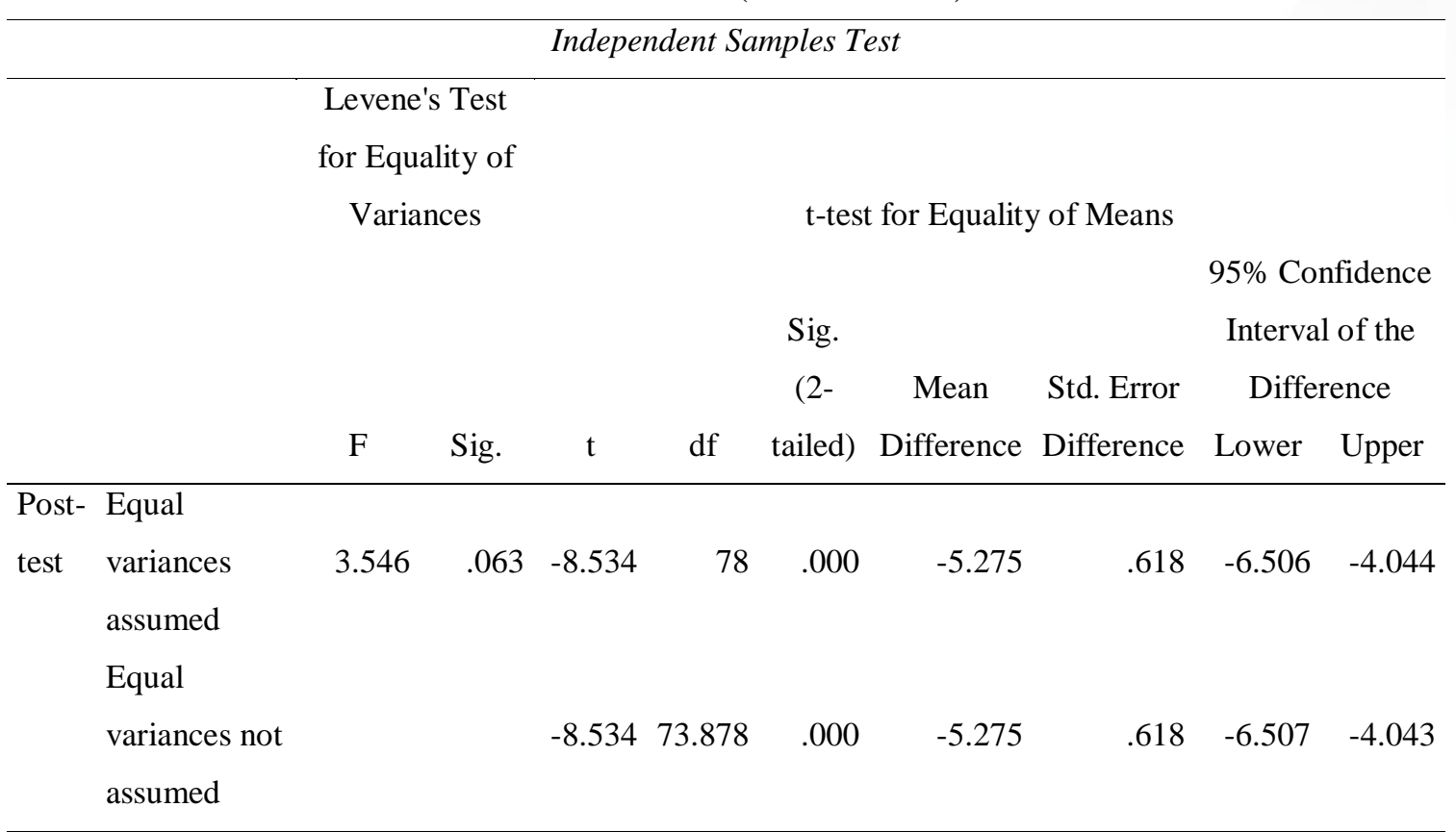

Created by: Remache (2022)

In the comparison of means, this test shows that the 2-tailed significance is .000 which is $<.005$. This is understood as there is a significant difference between the means of the pre and the posttest from the two groups of study.

As the table below shows, with $95 \%$ of confidence, the two tailed significance is .000 which is $<.005$. This means that there is great difference between the mean of the control group in the post-test and its similar in the experimental group. The latter had a 11.40 in its mean; however, the control group keeps the same low level of performance in the oral communication skills.

\section{Discussion}

The formation of a society whose objective is flexible learning at all educational levels, especially in higher education, is the main challenge of andragogy, considered as an art oriented to adult education (Castillo, 2014). On the other hand, the English language has always been a fundamental link of belonging to the community that is part of the current cultural diversity, present in the five continents as a lingua franca (Cristal, 2003).

The university student, as an adult learner, connects his experience with the new knowledge, skills and attitudes he acquires. Today, the nature of the linguistic need and the conditions for learning a foreign language in early adulthood, from 18 to 25 years of 
age, are determinants of its success or failure. For that reason, andragogy has turned into a "must" in the higher education.

While researching about the topic for this research, any previous research related to the topic was not found in the Escuela Superior Polytechnical de Chimborazo. At the beginning of the semester, the students did not show any interest in the English class. That could be the main reason for the low scores in the pre-test which are detailed in the previous section. Moreover, for the low level of English, it is said that students do not have enough opportunities to practice the language in oral form due to the cultural context they live (Barberán, 2017).

Taking into consideration that the classroom is the only place where students can practice their language skills, the intervention was designed which was focused on andragogic strategies to improve the oral communication skills. Those strategies were addressed during the whole semester which mainly proposed discussions in small groups or in pairs, analysis, simulation, the development of small projects, demonstrations. All these strategies include high order thinking skills to solve problems. In this way, the oral communication skills have been improved as the results in the post-test show.

\section{Conclusions}

After the intervention in the class, some conclusions come up:

- Due to the age of students in higher education, andragogic strategies were applied with successful results for students of first semester of the Industrial Maintenance career at the Escuela Superior Polytechnical de Chimborazo during the academic period October 2020 - March 2021.Those strategies aimed to help students in their improvement which was successfully achieved during an intervention process.

- The most suitable andragogic strategies for the students in the context of virtual learning were discussion, analysis, simulation, projects, demonstrations and problem solving. The students had the opportunity to interact and actively work in a communicational context.

- It is necessary to apply andragogic strategies in the university classrooms due to the population is formed by adults who have intrinsic motivation for learning.

\section{Bibliographical references}

Ahmed, M. (1989). Vocabulary learning strategies. Beyond words. 
Arifin, N. (2020). Enhancing Speaking Performance and Reducing Speaking Anxiety Using Ted Talks. Journal of Language Education and Educational Technology, 41-58.

Barberán, J. (2017, December 9). Enfoque comunicativo formal (PCA) en la producción oral del idioma inglés en la. Retrieved from Universidad Central del Ecuador Repositorio Digital: http://www.dspace.uce.edu.ec/bitstream/25000/13857/1/TUCE-0010-ISIP014-2017.pdf

Castillo, F. (2014). Andragogía. Procesos formativos entre adultos. Carteles Editores.

Clardy, A. (2005). Andragogy: Adult Learning And Education At Its Best? Andragogy Adult Learning , 1-44.

Concil of Europe. (2001). Common European Framework of Reference for Languages: Learning, Teaching, Assessment. Retrieved from https://rm.coe.int/16802fc1bf

Cristal, D. (2003). English as a Global Language. Cambridge University Press.

Dewi, R. S., Kultsum, U., \& Armadi, A. (2017). Using Communicative Games in Improving Students' Speaking Skills. English Language Teaching, v10 n1, 63-71

Harmer, J. (2007a). How to teach English. First Edition. Pearson Education.

Harmer, J. (2007b). The Practice of Language Teaching. Longman Publishers.

Knowles, M. (1976). The Adult learner: A neglected species. Gulf Publishing Company.

Knowles, M., Holton, F., \& Swanson, R. (2001). Andragogía: el aprendizaje de los adultos. Mexicana.

Machado, J. (2019, August 15). Primicias. Retrieved from Ecuador tiene el peor nivel de inglés de América Latina: https://www.primicias.ec/noticias/sociedad/idiomaingles-estudiantes-convenio-educacion-profesores/

Ministerio de Educación del Ecuador. (2016). Currículo 2016. Retrieved from https://educacion.gob.ec/curriculo/

Ortega Auquilla, D. P., \& Fernández, R. A. (2017). La Educación Ecuatoriana en Inglés: Nivel de Dominio y Competencias Lingüísticas de los Estudiantes Rurales. . Revista Scientific, 2(6), 52-73.

Peña, V. (2019, August 15). Enseñanza del inglés como lengua extranjera y desarrollo de competencias lingüísticas . Retrieved from Universidad Andina Simón 
Bolívar: https://repositorio.uasb.edu.ec/bitstream/10644/6603/1/T2833-MIEPe\%C3\%B1a-Ense\%C3\%B1anza.pdf

Richards, J., \& Rodgers, T. (1987). Approaches and Methods in language teaching. Cambridge University Press.

UNESCO. (2010, August 15). Informe Mundial sobre el Aprendizaje y la Educación de Adultos. Retrieved from UNESCO: https://uil.unesco.org/fileadmin/keydocuments/AdultEducation/es/GRALE_span isch.pdf

\section{Ciencia}


El artículo que se publica es de exclusiva responsabilidad de los autores y no necesariamente reflejan el pensamiento de la Revista Alfa Publicaciones.

\section{Ciencia}

El artículo queda en propiedad de la revista y, por tanto, su publicación parcial y/o total en otro medio tiene que ser autorizado por el director de la Revista Alfa Publicaciones.
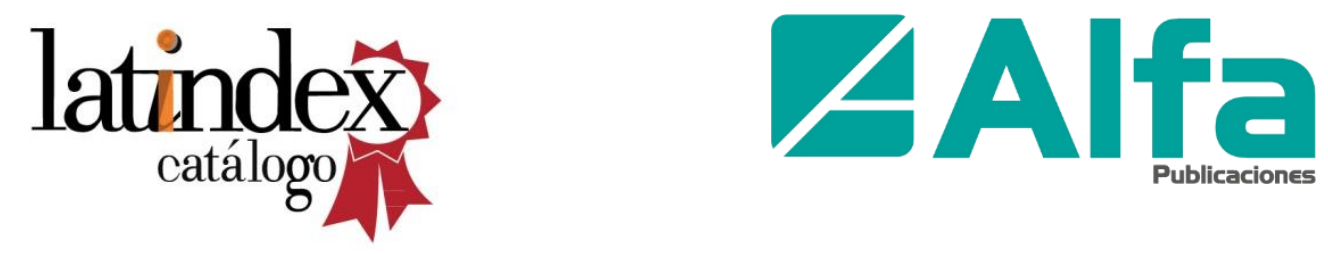

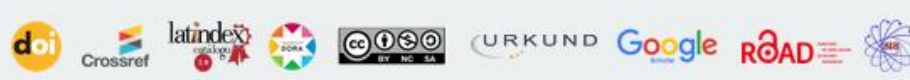
DLatinREV

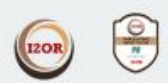

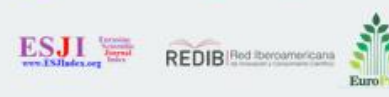
$\underbrace{}_{\text {wizdom.ai }} \bigodot_{\text {OpenAIRE }}^{+}$

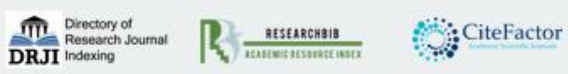

